Journal of Teaching and Learning with Technology, Vol. 10, Special Issue, pp. .337-353

doi: 10.14434/jotlt.v9i2.31621

\title{
Faculty Perceptions of Teaching Online During the COVID-19 University Transition of Courses to an Online Format
}

\author{
Shantia Kerr Sims \\ University of Central Missouri \\ skerr@ucmo.edu \\ David M. Baker \\ Tennessee State University \\ dmbaker@tnstate.edu
}

\begin{abstract}
As a result of the 2019 coronavirus disease pandemic, many universities were required to make quick decisions to accommodate social-distancing guidelines. Cherished university events such as commencement and spring convocations were postponed or canceled. Such decisions were made in an effort to curb the number of people infected with the virus. Institutions were also forced to consider how to continue educating students in the midst of a pandemic. In many instances, faculty were required to transition their face-to-face courses to an online format. Some instructors were familiar with the instructional strategies and technological tools needed for effective online teaching, whereas other, novice faculty were hesitant or even resistant to the idea of online teaching and learning. This case study at a Midwestern master's level university examines the perceptions of faculty $(N=183)$ regarding the quick transition of their courses to an online medium during the spring 2020 semester. We administered a web-based survey instrument consisting of two sections. Section I had 20 demographic questions and Section II had 28 statements rated on a 7-point Likert-type scale ranging from 1 (strongly disagree) to 7 (strongly agree). Section II assessed perceptions and attitudes about the quick transition to online, perceptions of students' engagement in the courses before and after the transition, and professors' level of satisfaction with the transition. The data were analyzed using frequency, mean, and analysis of covariance. Findings reveal that generally faculty felt that course quality remained the same, that students' engagement and performance declined during the pandemic, and that satisfaction levels with the transition were low.
\end{abstract}

Keywords: faculty perceptions, educational technology, student engagement, COVID-19, satisfaction.

The world is experiencing a global public health emergency. The 2019 coronavirus disease (COVID19) reveals how vulnerable and susceptible even the most advanced countries and health care systems are in an international crisis. Globally, at the time of this writing over 1 million people have died from COVID-19 and over 200,000 of those deaths have occurred in the United States (Hilsenrath \& Kamp, 2020). We are in the midst of a global pandemic and this is an unprecedented time for educational institutions. However, it is not the first time higher education has sustained and managed a pandemic. From the yellow fever outbreaks of the 1800s to the influenza outbreak (also referred to as the Spanish flu) of 1918, universities have endured quarantines and the need for distance learning (Thomas \& Foster, 2020). Specifically, during the influenza outbreak, college-age students were considered one of the most vulnerable populations and as a result higher education was directly impacted (Thomas \& Foster, 2020). Some colleges and universities responded to the pandemic by quickly closing and prohibiting students from attending face-to-face classes. According to Thomas and Foster (2020), other colleges, especially those considered more rural or isolated, stayed open and worked to ensure the safety of students, staff, and faculty. There was no universal response to how universities 
countered the impact of the influenza outbreak. Universities, like any other social institution, have had to face devastating epidemics that have impacted their day-to-day function.

The U.S. educational system experienced extraordinary challenges and opportunities as a result of the COVID-19 pandemic. Classes that were traditionally offered in a face-to-face setting were forced to transition to a distance-learning format. This abrupt change challenged teachers, administrators, parents, and students to teach, learn, and operate in a manner that previously had been only an option. Distance education became the primary method for teaching and learning. The COVID-19 pandemic has "created the largest disruption of education systems in history affecting nearly 1.6 billion learners in more than 190 countries and all continents" (United Nations Sustainable Development Group, 2020, p. 2). The massive effects of the pandemic on education can be observed throughout each continent. Social distancing, eliminating large gatherings, and preventative actions such as wearing masks have been identified as key measures to reduce the transmission of COVID19 (Centers for Disease Control and Prevention, 2020). Given the guidelines for slowing the spread of the virus, many educational units had to completely revamp their existing educational programs. Technological advances provide the opportunity for anywhere, anytime learning. From asynchronous to synchronous learning, there is tremendous promise and possibility in online learning. As a result of the COVID-19 social-distancing effort, there has been a large-scale transition to online learning (Govindarajan \& Srivastava, 2020).

Bastrikin (2020), of Education Data, an organization that seeks to make data about the U.S. education system more open and accessible, reported that 19.7 million students enrolled in courses at degree-granting postsecondary institutions in 2017. Findings revealed that 6.6 million of these students enrolled in some form of distance education or online learning course. Moreover, during the fall 2017 semester, 3.1 million students enrolled exclusively in distance education courses. Concerning faculty experience, in $2019,46 \%$ of faculty members stated they taught an online course for credit, compared to $39 \%$ in 2016. In 2019, 38\% of faculty used a blended or hybrid course format (including both online and face-to-face instruction). Additionally, $41 \%$ of instructors teaching online had used distance learning technology for less than 5 years, and less than $25 \%$ had taught online for at least 10 years (Bastrikin, 2020). The number of students enrolled in online learning has increased. Yet, the majority of faculty have less than 5 years of online teaching experience.

Govindarajan and Srivastava (2020) referred to a digital divide among faculty, where some are comfortable using course management systems, web conferencing tools, presentation software, and technologies for facilitating student learning, but others have never used such tools and were previously hesitant to learn about them. As faculty and universities transitioned to online learning during the COVID-19 pandemic, there was also the need for faculty to learn new technologies while teaching their content area. In reality, not all faculty have been involved in online learning. The ability of each faculty member to make an abrupt switch from face-to-face to online to continue teaching during the pandemic largely depended on their previous experience. The aim of this study was to examine faculty perceptions of teaching online during the pandemic and their satisfaction with the university transition.

\section{Literature Review}

Previous research indicates that online learners perform comparably to those in the face-to-face setting (Baker, Unni, Kerr-Sims, \& Marquis, 2020; Callister \& Love, 2016; Tallent-Runnels et al., 2006; Wilson \& Allen, 2011). In their research on skills-based courses, Callister and Love (2016) found that online students mastered some skills at the same rate as face-to-face students. Their sample of 134 students explored business negotiations in an online or face-to-face format. They showed no difference in their 
final exam grade or overall course grades. The research findings suggest that there is no significant difference in performance for the online and face-to-face student.

Although research has indicated that student performance in face-to-face and online settings is equivalent, there are still concerns among faculty regarding the different mediums of instruction. In their meta-analysis, Wingo, Ivankova, and Moss (2017) utilized an extended version of the technology acceptance model to explore factors that influence faculty's adoption and willingness to continue online teaching. Their findings revealed that faculty generally adapted to online teaching as they gained experience in the environment. Moreover, "faculty who were teaching online were gratified when institutions provided mentoring, training, support, and recognition of their success" (Wingo et al., p. 28). The desire for recognition of effort is well documented (Rockwell, Schauer, Fritz, \& Marx, 1999). The university plays a role in faculty satisfaction. Professional development, mentoring, and recognition of faculty efforts are key areas where administrators could work to support faculty through the online-teaching process.

Understanding the perceptions of faculty regarding online education is necessary to ensure instructors are effective and prepared in the classroom. Areas such as creating online assignments, managing grades, time management, and technical competencies (e.g., navigating the course management system, basic computer operations) are among the competencies faculty find most necessary for success in online teaching (Vang, Martin, \& Wang, 2020). Similarly, using the technological pedagogical content knowledge model, Houshmandi, Rezaei, Hatami, and Molaei (2019) explored the readiness of medical faculty for e-learning. Survey data and semistructured interviews were used to assess faculty readiness. Their findings reveal that although faculty members had a high level of pedagogical, content, and pedagogical-content knowledge, they perceived limited proficiency in their technological, technological-content, technological-pedagogical, and technologicalpedagogical-content knowledge. Faculty members were well versed in their content areas and pedagogical knowledge. However, their technology readiness was not ideal. Sustained technology professional development is needed to help ensure faculty feel prepared for online teaching.

Recognizing how faculty view online education will help guide the facilitation of online teaching and learning. Advancements in technology for education have propelled online education (Abraham, 2014). Benefits of technologies utilized in online learning include the ability to enhance communication between students and faculty and provide the flexibility and convenience of anywhere anytime learning, the potential to reduce feelings of intimidation through discussion board postings, and the opportunity to video record lectures for flipped learning (Singh \& Hurley, 2017). There are some advantages to utilizing technology for learning. However, despite these technological innovations, more research is needed to understand faculty readiness for online teaching, their technology use, as well as their perceptions of online courses (Martin, Budhrani, \& Wang, 2019; Otter et al., 2013).

Faculty workload is another area the online instructor must consider. Research has revealed concern regarding the perceived faculty workload of online teachers and their technical skill set (Bolliger \& Wasilik, 2009; Tabata \& Johnsrud, 2008). In a phenomenological inquiry on faculty perceptions of moving a face-to-face course online, Chiasson, Terras, and Smart (2015) uncovered primary conclusions from faculty experiences and perceptions. Ten faculty were interviewed, and through inductive analysis, several core themes emerged. Initially, faculty participants stated that planning and designing was more time intensive for an online course than for a face-to-face course. The researchers found it difficult to compare the total time required to teach face-to-face classes to the time for online courses because of the many factors to consider, including faculty lecture preparations, the initial effort it takes to start an online course, and the need to provide technical support to students. Faculty spent significant time with an instructional designer to learn the various instructional technology tools that would be used to support teaching and learning in their specific 
courses. Given the extensive development time and the professional development required, faculty believed they should have been compensated for the increased workload. The time it takes to develop and teach an online course has been documented by other researchers as well (Anderson, Rourke, Garrison, \& Archer, 2001; De Gagne \& Walters, 2009). Moreover, findings by Chiasson, Terras, and Smart (2015) revealed that teachers who taught synchronously (vs. asynchronously) deemed the instructional style as comparable. However, the asynchronous teachers had to utilize different instructional tools to provide an experience similar to face-to-face. Online teaching required faculty to be more efficient and effective educators. De Gagne and Walters (2009) findings revealed a need for sustained institutional support of online teaching.

Faculty have also expressed concerns regarding student success and student need for technical support. Factors that negatively impact faculty perceptions of online learning include unreliable technology infrastructure. When provisions for technical support are in place and can decrease the technical difficulty faculty may endure and have to troubleshoot, there is an increase in faculty satisfaction (Fredericksen, Pickett, Shea, Pelz, \& Swan, 2000; Hartman, Dziuban, \& Moskal, 2000). In addition to technical support, lack of access to appropriate technologies also plays a role in the perceived satisfaction of online teachers (Bolliger \& Wasilik, 2009). Institutional support that recognizes the unique challenges of online faculty, including the need for technical support and access to appropriate technology, is required.

Online learning has provided an alternative to face-to-face teaching in the midst of the COVID-19 pandemic. Many colleges were forced to quickly identify alternatives to face-to-face instruction that would address the need for social distancing while continuing to provide a high-quality education to students. Some of the challenges associated with online teaching and learning include the time and effort required to develop an online curriculum as well as technology access and support.

This study aimed to answer the following research questions:

- What are faculty perceptions of online education?

- What were faculty perceptions of student learning and engagement before and during the pandemic in spring 2020?

- What was the level of faculty satisfaction with the transition of courses from face-to-face to online course delivery in spring 2020 ?

\section{Method}

\section{Participants and Procedures}

The study population consisted of the entire population of faculty at a Midwestern master's level university who taught courses during the spring of 2020. After receiving Institutional Review Board approval, we sent an online survey using Qualtrics to all faculty via the university email system. Faculty had to give informed consent, after which they were provided with information about the study and a link to the online faculty satisfaction survey. Participants needed to click into the Qualtrics secure server site to complete the survey, which took approximately $8 \mathrm{~min}$. All responses were anonymous and confidential. After 5 days, a follow-up email reminder was sent out. Inclusion in the study was voluntary in a nonprobability sampling. The response rate was $40.22 \%(n=183)$. The majority of responders were female $58.9 \%$ (with male responders at $39.2 \%$ ). Their ages ranged from 32 to 75 years ( $M=50$ years $)$ and $72 \%$ had online teaching experience. 


\section{Questionnaire}

The survey instrument was developed on the basis of the results of the literature review, which included articles pertaining to faculty satisfaction with online education as well as student engagement. Questions from those previous studies were used to construct the instrument for this study. The final draft was then critiqued by professors in various disciplines who had teaching experience with both face-to-face and online classes, ranging in teaching experience from 10 to 45 years. They suggested several modifications that were implemented. The final instrument was divided into two parts: Section I consisted of 20 questions on faculty demographics, including age, race, gender, teaching experience, class size, and transition to online teaching. had 28 items which were developed for each of the five subscales: (a) Student-Faculty Interaction, (b) Student-Student Interaction, (c) Effective Teaching Practices, (d) Technology Interaction, and (e) Supportive Environment. A 7-point Likert-type scale of 1 (strongly disagree) to 7 (strongly agree) was used. To determine the internal reliability of the questionnaire, a reliability analysis with Cronbach's alpha was done after the data collection phase.

\section{Data Analysis}

The raw data from Qualtrics was exported to SPSS version 23. The data were comprehensively checked using the exploratory data analysis (EDA) technique, a technique that helps quantitative researchers understand their data, identify errors or outliers that exist, and fix those issues (Masciari, 2011). EDA was performed by computing various statistical analyses and meeting assumptions before analyzing any descriptive and inferential statistics. Then the descriptive analysis was conducted to describe the profile of faculty demographics. Cronbach's alpha was computed to determine the questionnaire's internal consistency. The alpha values ranged from .60 to .83 . To investigate the research questions, we calculated descriptive statistics (frequencies, means, and standard deviations) and ran an analysis of covariance using IBM SPSS statistical software (version 23.0). No faculty were identifiable in the data under analysis for this contrast, and no study data could be mapped back to any individual faculty member; that is, the data were anonymous.

\section{Results}

The initial sample consisted of 183 faculty. A few of the respondents had significant missing data. Those who did not complete Section II $(n=25)$ were deleted from the analysis, leaving a final sample of $N=158$. Respondents were representative of all colleges within the university. Instructors' smallest class size mean was 15 students and largest was 32 students. The average overall teaching experience consisted of 17 years. What faculty liked most about teaching online was the convenience of being able to teach from anywhere $(62 \%)$. Faculty least liked the limited face-to-face interaction with students $(71 \%)$. The remaining sample characteristics are shown in Table 1.

Table 1. Demographic faculty profile.

\begin{tabular}{lcc}
\hline Variable & $n$ & $\%$ \\
\hline Gender & & \\
Male & 62 & 39.2 \\
Female & 93 & 58.9 \\
Age (years) & & \\
$21-34$ & 18 & 11.3 \\
$35-44$ & 44 & 27.8 \\
\hline
\end{tabular}

Journal of Teaching and Learning with Technology, Vol. 10, Special Issue, jotlt.indiana.edu 


\begin{tabular}{|c|c|c|}
\hline Variable & $n$ & $\%$ \\
\hline $45-54$ & 40 & 25.3 \\
\hline $55-64$ & 43 & 27.2 \\
\hline$>65$ & 11 & 7 \\
\hline \multicolumn{3}{|l|}{ Race/Ethnicity } \\
\hline African American/Black & 3 & 1.9 \\
\hline Asian & 6 & 3.8 \\
\hline Caucasian/White & 139 & 88 \\
\hline Hispanic & 3 & 1.9 \\
\hline \multicolumn{3}{|l|}{ Highest degree earned } \\
\hline Master's & 42 & 26.6 \\
\hline Ph.D. & 107 & 67.7 \\
\hline \multicolumn{3}{|l|}{ Current rank } \\
\hline $\begin{array}{l}\text { Full-time tenured } \\
\text { professor }\end{array}$ & 48 & 30.4 \\
\hline $\begin{array}{l}\text { Full-time tenured } \\
\text { associate professor }\end{array}$ & 29 & 18.4 \\
\hline $\begin{array}{l}\text { Full-time tenure-track } \\
\text { assistant professor }\end{array}$ & 29 & 18.4 \\
\hline $\begin{array}{l}\text { Full-time nontenured } \\
\text { professor }\end{array}$ & 29 & 18.4 \\
\hline Adjunct professor & 20 & 12.7 \\
\hline \multicolumn{3}{|l|}{ Time to transition } \\
\hline Less than 1 week & 22 & 13.9 \\
\hline About 1 week & 64 & 40.5 \\
\hline About 2 weeks & 63 & 39.9 \\
\hline More than 2 weeks & 5 & 3.2 \\
\hline \multicolumn{3}{|l|}{ Online teaching experience } \\
\hline None & 5 & 3.2 \\
\hline First time during COVID- & 41 & 25.9 \\
\hline \multicolumn{3}{|l|}{19 transition } \\
\hline Some (1-2 years) & 40 & 25.3 \\
\hline Significant ( $\geq 5$ years) & 72 & 45.6 \\
\hline
\end{tabular}

Note. A few of the respondents had significant missing data. Time to transition refers to the transition from face-to-face to online classes during the 2019 coronavirus disease (COVID-19) pandemic.

\section{Analysis}

Analysis of covariance was used to test the main and interaction effects of the categorical variables on a continuous dependent variable, controlling for the effects of selected other continuous variables, which covary with the dependent. This was carried out to test for differences in the mean. The independent variables examined were gender, age, qualifications (masters vs. doctoral and tenure status (tenure vs. non-tenured). The dependent variables examined were (a) overall, I believe that my online instruction during the COVID-19 pandemic met the same quality standards as when I was teaching the courses face-to-face; (b) overall, I believe that my students' performance and completion of the course with a good grade was not significantly affected by the transition of my face-to-face classes to 
online during the COVID-19 pandemic; (c) overall, I am very satisfied with the transition of my courses from face-to-face to online during the COVID-19 pandemic in spring 2020; (d) I am excited to get back on campus in the near future and teach my courses in the traditional face-to-face setting.

There was no significant difference between men $(M=2.52)$ and women $(M=2.39)$ in comfort level with online teaching; there were no significant differences in age $(<45$ years: $M=2.65$, $>44$ years: $M=2.27$ ), tenure status (tenured: $M=2.39$, nontenured: $M=2.44$ ), or qualifications (Ph.D.: $M=2.27$, master's: $M=2.65$ ). There were no significant differences in any variables in preference for online courses as well.

However, when "comfort level with online teaching" and "overall teaching experience" were used as covariates, the results revealed a significant effect on key dependent variables, as seen in Table 2. Age was significant, and faculty younger than 45 years $(M=3.44)$ were less in agreement than faculty older than $44(M=4.08)$ with the statement that online instruction during the COVID-19 pandemic met the same quality standards. Thus, younger faculty felt that their face-to-face classes taught before the pandemic had higher quality standards. Overall faculty believed that quality remained about the same.

Table 2. Analysis of covariance results ( $p$ values).

\begin{tabular}{|c|c|c|c|c|}
\hline Item & $\begin{array}{c}\text { Age } \\
(<45 \text { years vs. }>44 \text { years })\end{array}$ & Gender & $\begin{array}{l}\text { Tenure vs. } \\
\text { nontenure }\end{array}$ & $\begin{array}{l}\text { Ph.D. vs. } \\
\text { master's }\end{array}$ \\
\hline $\begin{array}{l}\text { Overall, I believe that } \\
\text { my online instruction } \\
\text { during the COVID-19 } \\
\text { pandemic met the } \\
\text { same quality standards }\end{array}$ & .01 & .145 & .112 & .646 \\
\hline $\begin{array}{l}\text { Overall, I believe that } \\
\text { my students } \\
\text { performance and } \\
\text { completion of the } \\
\text { course with a good } \\
\text { grade was not } \\
\text { significantly affected }\end{array}$ & .011 & .088 & .066 & .131 \\
\hline $\begin{array}{l}\text { Overall, I am very } \\
\text { satisfied with the } \\
\text { transition of my } \\
\text { courses }\end{array}$ & .069 & .042 & .057 & .153 \\
\hline $\begin{array}{l}\text { I am excited to get } \\
\text { back on campus in } \\
\text { the near future }\end{array}$ & .675 & .110 & .137 & .800 \\
\hline
\end{tabular}

Note. Bold indicates significance. COVID-19 = 2019 Coronavirus disease.

Regarding students' engagement and performance, age, gender, and tenure status were found to be significant. Faculty younger than 45 years $(M=3.55)$ were much less in agreement than faculty older t4 $(M=3.92)$ with the statement that students' performance and completion of the course with a good grade was not significantly affected, meaning that younger faculty felt that the transition of their face-to-face classes to online did indeed negatively affect student engagement and the possibility of them getting a good grade. Gender was significant, with more male faculty feeling that the transition of their face-to-face classes to online did indeed negatively affect student engagement and the 
possibility of them getting a good grade. Tenure status was also significant, with tenured faculty $(M=$ 3.47) being far more likely than nontenured faculty $(M=4.07)$ to believe that the transition of their face-to-face classes to online did indeed negatively affect student engagement and the possibility of them getting a good grade. Overall, faculty perceptions of students' engagement and performance declined during the pandemic.

Age, gender, and tenure status were found to be significant for level of satisfaction with the transition to online classes. Faculty younger than 45 years $(M=3.69)$ were much less satisfied with the transition of courses to online than faculty older $4(M=4.11)$. Male faculty $(M=3.58)$ were far less satisfied with the transition than female faculty $(M=4.16)$. Tenured faculty $(M=3.72)$ were less satisfied with the transition than nontenured faculty $(M=4.16)$. Overall, faculty were slightly satisfied with the transition; therefore, the satisfaction level was low.

\section{Institutional Support}

The online environment can present challenges for many professors who increasingly are required to improve their levels of technological competency and proficiency to match technological innovations especially as it relates to videoconferencing, slide show presentations, and class groups. The literature review revealed that university technology infrastructure, technical support, university training to improve professors' technical skill set, and faculty work load all have some effect on the success of online courses. Orlando and Attard (2015) stated that "teaching with technology is not a one size fits all approach as it depends on the types of technology in use at the time and also the curriculum content being taught" (p. 119). Hence, different universities will encounter different challenges as they implement online learning utilizing their specific technologies, and teaching pedagogy, design, and construction of learning experiences and level of technology support will not be the same for all institutions. Although there are numerous technologies available for integration into the classroom, it is still "taken for granted" that they can be used to enhance learning (Kirkwood \& Price, 2014, p. 6). Adapting to the online environment and effectively utilizing the technology can be a challenge for both teachers and students (Jaques \& Salmon, 2007; Kirkwood \& Price, 2014). In the current study there was a low level of faculty agreement with the statements concerning institutional technological support for the transition of classes from a face-to-face format to online delivery. There were no significant differences between the opinions of males and females. Table 3 show the descriptive results.

Table 3. Descriptive statistics for two dependent variables.

\begin{tabular}{lccccc}
\hline Variable & $N$ & $M$ & $S D$ & $S E$ & $95 \%$ CI lower bound \\
\hline \multicolumn{2}{l}{ My institution ensured that faculty had all the equipment } & and & technology needed to be successful \\
Men & 61 & 3.75 & 1.88 & .240 & 3.27 \\
Women & 92 & 4.13 & 1.99 & .207 & 3.72 \\
Total & 153 & 3.98 & 1.95 & .157 & 3.67 \\
My institution offered faculty & enough assistance & and training to engage in online learning \\
Men & 61 & 3.98 & 1.66 & .212 & 3.56 \\
Women & 92 & 3.91 & 1.78 & .185 & 3.55 \\
Total & 153 & 3.94 & 1.73 & .139 & 3.67 \\
\hline
\end{tabular}

Note. CI $=$ Confidence interval. 


\section{Discussion}

\section{Online Teaching}

One of the factors explored by this study is faculty perceptions of online education. The move to online instruction provides the flexibility of anywhere, anytime learning. However, most universities were required to complete this change within 1 to 2 weeks during the COVID-19 pandemic. Most universities have Centers for Teaching and Learning or other faculty professional development entities to support faculty members in their desire to learn about online learning. However, it is unlikely that during the COVID-19 pandemic, professional development and support could be offered at the same level to all faculty. Hence, it is unreasonable to compare face-to-face and online instruction (Hodges, Moore, Lockee, Trust, \& Bond, 2020). Faculty were still responsible for teaching and ensuring learning objectives were met while providing a positive learning environment. Similarly, students were also responsible for their role in the learning process. An understanding of the perception of the transition will provide insight into how faculty viewed the swift change to online learning. However, student and instructor responsibility through the shift did not change.

There are a myriad of ways that COVID-19 has impacted faculty members and their careers, with emergency transitions to online teaching, disruptions to nearly all research activities, and added service and mentoring work. Instructors who are new to the online learning environment may have felt anxiety about how best to provide their students with the learning experience they deserve. According to Thormann and Zimmerman (2012), when faculty lack proficiency with technology it may be a result of a lack of time for technology training versus resistance to technology. In a study by Lokken and Mullins (2014), distance education administrators were asked to rank their greatest faculty challenges in the 2013 Instructional Technology Council survey. The findings revealed that engaging in online pedagogy was a major faculty concern. Research has shown that teaching experience is positively associated with student achievement gains throughout a teacher's career. Gains in teacher effectiveness associated with experience are most steep in teachers' initial years but continue to be significant as teachers reach the second, and often third, decade of their careers. The results of this study support these findings.

\section{Quality}

A majority of administrators and some faculty believe that online learning is comparable or superior to face-to-face learning (Allen \& Seaman, 2013). However, the rush to facilitate online learning through the pandemic may perpetuate the long-standing stigma of online learning being inferior. Reisetter, LaPointe, and Korcuska (2007) reviewed whether online and face-to-face learners were similarly content with the quality of their learning. Their findings showed that the two class formats scored equally with regard to learning outcomes and satisfaction, even though learners had absolutely different learning experiences. However, critics have argued that because of intrinsic differences, online education does not duplicate the learning that occurs in the traditional classroom (Bejerano, 2008). Participants in the current study provided support for the assertion that there was no significant difference in the quality of their face-to-face courses after they were transitioned online during the pandemic.

\section{Student Engagement}

The online instructor's role is very important to the success of online learning. The advent of online learning, lecture-based classes online, and the transformation of the instructor role requires a modality 
shift (Easton, 2003). Through the use of discourse analysis, Beck and Ferdig (2008) revealed that in online learning, the role of the teacher shifted from teacher centered to student centered, from low interaction to high interaction, and from low initiator to high initiator. Dixson's (2010) study of online student engagement surveying 186 students from six campuses in the Midwest found that there was no particular activity that automatically facilitates student engagement in online classes. Instead, the results indicate that multiple communication channels may be related to higher engagement and that student-student and instructor-student communication were clearly strongly correlated with higher student engagement with the course in general. In another study, Buelow, Barry, and Rich (2018) investigated the concept of online student engagement in a survey of 417 students. Course activities that had statistical significance in relations to students' reported learning activities changed their understanding of a topic or concept, connected their learning to societal problems, linked their learning to prior experiences and knowledge and were interpreted as fun. Students were engaged when learning was fun, relevant, and applicable to the real world. Farrell and Brunton (2020) conducted a qualitative study that explored online student engagement experiences in a higher education institution. Their findings indicated that successful online student engagement was influenced by a number of psychosocial factors such as peer community, an engaging online teacher, and confidence and structural factors such as life load and course design. For the current study, faculty perceptions of students' engagement and performance declined during the pandemic with the transition from faceto-face to online instruction.

There are distinct differences between thoughtfully developed online learning experiences and online learning as a result of a crisis (Hodges et al., 2020). A swift, temporary shift to online teaching and learning is commonly referred to in the literature as emergency remote teaching. This emergency mode of teaching and learning as a direct result of the COVID-19 pandemic, created challenges for both students and teachers. The challenges of emergency remote teaching can help explain our finding that faculty perceptions of students' engagement and performance declined during the pandemic. According to Heckel and Ringeisen (2019), attitude toward online learning is based on previous experience with technology. Similarly, Siron, Wibowo, and Narmaditya (2020) found that students who lacked adequate prior experience with online learning and corresponding technological tools perceived emergency remote teaching as forced. Instead of the primary focus resting on the learning experience, there were difficulties related to technology proficiency. As previously mentioned, online college course offerings have grown rapidly. Yet, there are still many students who have not taken online courses. The lack of prior online learning experience challenges the switch to emergency remote teaching and learning.

The U.S. Department of Education (2019) data reveal that the percentage of all college students who enrolled in at least one distance learning course grew from $33.5 \%$ in 2017 to $35 \%$ in 2018. Although online enrollments increased by the year 2018, all students had not completed a distance education course or utilized technology in a way that would facilitate meaningful learning in an online course. Not having prior experience with online learning could have posed challenges as it relates to student engagement and perceptions during the emergency remote teaching and learning experienced in the pandemic. Brooks and Pomerantz's (2017) research on undergraduate students and information technology revealed that $97 \%$ of students owned a smartphone, $95 \%$ owned a laptop, and approximately $50 \%$ owned a tablet. The researchers attributed the difference in the number of laptops versus tablets students owned to the type of work that could be produced on a laptop versus a tablet. However, owning a laptop or cellphone does not mean the technology will work the same across all online teaching platforms. For example, a small screen size, short battery life, and limited internet connection can all impact online learning (Joo, Kim, \& Kim, 2016). There are some negative functional aspects related to using a learning management system (LMS) with a mobile device. 
Access to appropriate technology is necessary for a positive learning experience. According to the Global Strategy Group (2020), to ensure continuity in their online learning, during the spring 2020 semester, $44 \%$ of college students had to purchase a computer or laptop and $17 \%$ had to purchase internet service. Their findings revealed that the percentages of students who needed to purchase technology were higher among Latino and Latina students $(52 \%$ and $19 \%$, for computers and internet, respectively) and African American students (55\% and 32\%, respectively). Having limited access to high-speed internet influences students' timely access to learning materials and their participation in online interactions, thus negatively affecting student engagement. Moreover, students' accessibility and mobility have some effect on their level of engagement. Accessibility includes access to reliable internet service and the use of cloud and conferencing applications (e.g., BlueJeans, Google Meet, Microsoft Teams, and Zoom) as well as any LMS. Students' ability to use their devices without any time or place restriction allowing $24 / 7$ access is ideal. For students who only own a cellphone and do not have access to other technologies, the learning experience and engagement can be compromised.

In the Global Strategy Group (2020) survey, 57\% of college students reported that access to a high-speed, stable internet connection posed a challenge in the transition to online learning during the emergency remote learning in spring 2020. Similarly, prior to the emergency remote teaching resulting from the COVID-19 pandemic, Gierdowski (2019) found that 65\% of undergraduate respondents rated their on-campus Wi-Fi login experiences as favorable, with libraries providing the most reliable Wi-Fi connection for students on campus. The study also found $60 \%$ of the wireless access in student housing and dorms was rated as positive while outside spaces received the lowest rating for reliable internet access. During a pandemic, when students are required to be socially distant, reliable high-speed internet in outside spaces and in student homes could provide a safe option for the internet access needed for successful online learning.

In addition to technology access, there have been other factors that challenge students' online learning during the COVID-19 pandemic. Aguilera-Hermida (2020) identified situational and environmental challenges, online educational challenges, and emotional challenges as factors affecting students' online learning. The ability to concentrate at home was the biggest challenge to respondents' online learning. There were many distractions and concerns at home for students, such as family members, noise, time management, housework, stress, anxiety, food and job insecurity, and being worried about contracting the coronavirus. All of these factors could affect student focus and participation in class, thus affecting student engagement (Aguilera-Hermida, 2020). Student engagement is affected by factors inside and outside the classroom setting.

\section{Faculty Satisfaction With the Transition During the COVID-19 Pandemic}

There have been difficulties in the implementation of the change process in the education system put in motion as a result of the COVID-19 crisis; these difficulties are related to the novel perspectives of online education and their technological complexities. The development of online courses in higher education does not just happen overnight, and faculty do not necessarily possess the technological competence to embrace the swift change that was required at the outset of the pandemic. The results of the present study reveal that at this Midwestern university, $29 \%$ of the professors had never taught an online course. It is unlikely that they would have the capability to start teaching each of their courses online at a moment's notice. To teach effectively online, faculty must possess content knowledge, computer proficiency, and the capacity to conduct minor technological trouble shooting, as well as other teaching, social, and technical skills. As teachers began to teach in the pandemic, some of their challenges included not having the appropriate technologies at home and the lack of professional development in the area of online teaching. 
Stickney, Bento, and Apparwat (2019) found that higher education faculty who taught online were generally satisfied, and that their satisfaction was more likely if there was appropriate training and if teaching online allowed for flexibility in their schedules. Although a weaker relationship, results also suggested that faculty were more satisfied teaching online when the institutional and organizational policies supported faculty online teaching efforts. Factors influencing faculty satisfaction with online teaching and learning in higher education have been investigated relatively few times, but according to Stickney, et. al. (2019) faculty satisfaction is considered an important factor in the quality in online courses. Similarly, Bolliger and Walisik (2009) conducted a study to identify and confirm factors affecting the satisfaction of online faculty at a small research university. An online faculty satisfaction survey was developed and administered to all instructors who had taught an online course in the 2007-2008 academic year. One hundred two instructors completed the web-based questionnaire. Results confirm that the factors affecting the satisfaction of faculty in the online environment fall into three categories: those related to students, to instructors, and to institutions. In the current study, the results revealed that there was a low level of faculty agreement with the statements concerning institutional technological support for the transition of their classes from a face-to-face format to online delivery. The findings also revealed that faculty were slightly satisfied with the transition of their courses from face-to-face to online instruction during the pandemic.

\section{Conclusion}

This research found that at the start of the COVID-19 pandemic, the majority of the faculty members who were not already teaching online transitioned from traditional face-to-face to an online instructional model. A small subset of faculty were unable to fully move their courses online. Findings revealed that younger faculty in this study were less confident than older faculty with the notion that their online instruction met the same quality standards as their face-to-face instruction. However, overall, faculty believed that quality remained about the same. Faculty appreciated the convenience of online teaching but felt their engagement and interaction with students was limited in comparison to the traditional face-to-face setting. Tenured faculty were far more likely than nontenured faculty to believe that the transition of their face-to-face classes to online negatively affected student engagement. Overall, faculty perceptions of students' engagement and performance declined during the pandemic.

The following recommendations are provided to inform faculty members and university administration on methods that can be used to support faculty in quick transitions to online learning and online learning generally. Recommendations address the need for sustained technology professional development, mentorship by discipline as needed and administrative technology planning.

\section{Sustained Technology Professional Development}

When online learning is mandated, such as during a pandemic, the teaching and learning experience inherently becomes more complex. Preparation for technology-enhanced learning should occur before it is needed. There should be ongoing support of faculty, especially nontenured faculty who may not be as confident in instructional methodology regardless of the setting. Nontenured faculty in this study were less confident in the quality of their online courses in comparison to their face-to-face courses. Providing sustained technology professional development with strategies for effective online teaching would help faculty feel more confident. A university's Center for Teaching and Learning or other faculty-focused, professional development department could provide guidance in this area. 


\section{Discipline-Specific Mentorships}

Specific content areas may consider mentoring to ensure content-area technology and strategies are used effectively in the online setting. The support of a mentor in the field could help faculty feel more confident in their ability to teach in both face-to-face and online settings. Some disciplines have labs and utilize technologies that are specific to their content area. Working with a mentor could help faculty learn content-specific technologies while also ensuring the mentee has solid instructional design and an online teaching strategy.

\section{University-Level Technology Planning}

Most universities have a technology or distance learning committee. They usually inform administration and develop policies and guidelines for online teaching and learning. However, at the start of the pandemic, when a swift change of learning modalities was required, some faculty and students needed additional guidance and technology. Technological tools (e.g., hotspots, laptops, tablets) were needed for the continuity of learning. Relationships with technology providers to support the infrastructure for remote learning could also assist in this endeavor. Guidance and policies for a quick shift to online learning in the event of a global health, security, or other national or international crisis should be developed.

\section{Limitations}

This study explored perceptions of faculty members at one Midwestern master's level university. Therefore, the study represents a specific population group and may not be representative of all faculty at all institutions of higher education. University faculty adapted their courses to meet student learning needs. Some faculty engaged in this process with minimal formal training or experience with online teaching. In addition to the need for social distancing required during the pandemic, it is appropriate to acknowledge the various needs of faculty and students during this time. From their own health concerns to the loss of internships, dislocation of homes, and competing responsibilities of caring for children or older adults who were unable to continue in their everyday activities, the lives of many students and teachers changed during the pandemic. The findings of this study support the need for sustained technology professional development, mentorships of nontenured or junior faculty with more experienced, tenured faculty, and additional layers of technological planning at this university. Future research should focus on student perceptions of the transition to online learning during the COVID-19 pandemic, additional faculty experiences during the transition at other universities, and opportunities for institutional support of faculty and students engaged in online learning.

\section{Epilogue}

The switch to emergency remote learning during the spring of 2020 revealed the resilience of faculty and students as well as the sincere desire to see students succeed. Faculty were dedicated in their pursuit and support of students. For example, experienced and novice faculty were eager to learn new strategies and tools to effectively teach their online students. Faculty and university departments such as the Center for Teaching and Learning offered professional development and mentoring to other faculty as needed. The few faculty who did not engage in online learning identified creative instructional strategies to ensure their own safety as well as the safety of their students. In addition to resilience and dedication, grace was given and received from faculty and students. Both groups were 
under immense pressure and uncertainty in the initial move to remote emergency teaching. Acknowledging their multiple competing responsibilities and concerns, faculty looked beyond content area teaching and learning to make deeper connections with students. Moreover, administration moved quickly implement a plan to support faculty and students who needed access to technology (laptops, hotspots, etc.). There were gaps in access from students owning technology to rural students who did not have access to high-speed internet in their homes and community. The University recognized the needs of both faculty and students and moved to swiftly accommodate them. The important work of emergency distance learning preparedness must continue as all universities refine their policies to ensure the continuity of learning in the midst of unprecedented circumstances. Though unexpected, the pandemic gave the university the opportunity to support students and faculty, realize gaps in the distance learning plan and reinforce the mission of educating all students.

When institutions started sending students and professors home due to COVID-19, I was first concerned about students who do not have good access to technology. I know some of them have never done online courses but given their use of technology I figured it would not be that hard for them to learn even in an emergency setting. Secondly I thought, wow I have a little bit more time on my hands since the situation is in chaos so I can be more productive with my research. Then it dawned on me that I was being promoted to full professor this year and whether or not that will still occur, the good news is, it did. Then I worried about tenure-track faculty but many institutions were offering tenure-clock stoppages, for example, to mitigate junior faculty members' concerns about losing months of writing and research time to coronavirus-related disruptions. Others were looking at different ways of supporting professors on and off the tenure track who were struggling with the logistical and emotional tolls of COVID-19.

Since spring I have been trying to seek out different ways of grading and experimenting with alternative modes of assessment. Another key concern I still have is about students' class attendance. Attendance remains a challenge, even though we know that typically attendance lags as the term goes on in every undergrad class every year. The key difference now is that I know more about why they aren't there. I get information from the reflections about their serious struggles to juggle the time required for heavy course loads, their work schedules, and their honest struggles to remain focused and committed when they are still sorting out their lives. At the end of the day we are trying to be as resilient as possible, hopeful for a better tomorrow and reasonable with students who are trying to cope. We are trying our best to still ensure that students are learning as much as possible of the material even during a pandemic.

\section{References}

Abraham, S. E. (2014). Online education: Perceptions of faculty and administrators at three different types of institutions of higher education (Unpublished doctoral dissertation, East Tennessee State University). Retrieved from https: / /dc.etsu.edu/cgi/viewcontent.cgi?article $=3701 \&$ context $=$ etd

Aguilera-Hermida, P. (2020). College students' use and acceptance of emergency online learning due to COVID-19. International Journal of Educational Research Open, 1(1), Article 100011. https://doi.org/10.1016/j.ijedro.2020.100011

Allen, I. E., \& Seaman, J. (2013). Changing course: Ten years of tracking online education in the United States. Babson Park, MA: Babson Survey Research Group and Quahog Research Group. Retrieved from http://www.onlinelearningsurvey.com/reports/changingcourse.pdf

Anderson, T., Rourke, L., Garrison, R., \& Archer, W. (2001). Assessing teaching presence in a computer conferencing context. Online Learning, 5(2). http://dx.doi.org/10.24059/olj.v5i2.1875 
Baker, D., Unni, R., Kerr-Sims, S., \& Marquis, G. (2020). Understanding factors that influence attitude and preference for hybrid course formats. e-Journal of Business Education \& Scholarship of Teaching, 14(1), 174-188.

Bastrikin, A. (2020, April 12). Distance learning statistics [2020]: Online education trends. Retrieved from https://educationdata.org/online-education-statistics

Beck, D., \& Ferdig, R. E. (2008). Evolving roles of online and face-to-face instructors in a lecture/lab hybrid course. Turkish Online Journal of Educational Technology, 7(1). Retrieved from http://eric.ed.gov/?id=ED499577

Bejerano, A. R. (2008). The genesis and evolution of online degree programs: Who are they for and what have we lost along the way? Communication Education, 57(3), 408-414. https://doi.org/10.1080/03634520801993697

Bolliger, D. U., \& Wasilik, O. (2009). Factors influencing faculty satisfaction with online teaching and learning in higher education. Distance Education, 30(1), 103-116. https://doi.org/10.1080/01587910902845949

Brooks, D. C., \& Pomerantz, J. (2017). Educause Center for Analysis and Research ECAR Study of Undergraduate Students and Information Technology. Retrieved from https://library.educause.edu/Lmedia/files/library/2017/10/studentitstudy2017.pdf

Buelow, J. R., Barry, T., \& Rich, L. E. (2018). Supporting learning engagement with online students. Online Learning, 22(4), 313-340. https://doi.org/10.24059/olj.v22i4.1384

Callister, R. R., \& Love, M. S. (2016). A comparison of learning outcomes in skills-based courses: Online versus face-to-face formats. Decision Sciences Journal of Innovative Education, 14(2), 243256. https://doi.org/10.1111/dsji.12093

Centers for Disease Control and Prevention. (2020, July). Social distancing. Keep a safe distance to slow the spread. Retrieved from https://www.cdc.gov/coronavirus/2019-ncov/prevent-gettingsick/social-distancing.html

Chiasson, K., Terras, K., \& Smart, K. (2015). Faculty perceptions of moving a face-to-face course to online instruction. Journal of College Teaching \& Learning, 12(3), 321-240. https://doi.org/10.19030/tlc.v12i3.9315

De Gagne, J. C., \& Walters, K. (2009). Online teaching experience: A qualitative metasynthesis (QMS). Journal of Online Learning and Teaching, 5(4), 577-589.

Dixson, M. (2010). Creating effective student engagement in online courses: What do students find engaging? Journal of the Scholarship of Teaching and Learning, 10(2), 1-13.

Easton, S. S. (2003). Clarifying the instructor's role in online distance learning. Communication Education, 52(2), 87-105.

Farrell, O., \& Brunton, J. (2020). A balancing act: A window into online student engagement experiences. International Journal of Educational Technology in Higher Education, 17, Article 25.

Fredericksen, E., Pickett, A., Shea, P., Pelz, W., \& Swan, K. (2000). Factors influencing faculty satisfaction with asynchronous teaching and learning in the SUNY learning network. Journal of Asynchronous Learning Networks, 4(3), 245-278. http://dx.doi.org/10.24059/olj.v4i3.1897

Gierdowski, D. C. (2019). Educause Center for Analysis and Research (ECAR) Study of Undergraduate Students and Information Technology. Retrieved from https://library.educause.edu/$\angle$ media/files/library $/ 2019 / 10 /$ studentstudy2019.pdf?la $=$ en\&hash=25FBB396AE482FAC3 B765862BA6B197DBC98B42C

Global Strategy Group. (2020). New America and Third Way Higher Ed Student Polling Data, August 6-17, 2020 [Polling data]. Retrieved from thirdway.imgix.net/New-America-andThird-Way-Higher-Ed-Student-Polling-Data.pdf

Govindarajan, V., \& Srivastava A. (2020, March 31). What the shift to virtual learning could mean for the future of higher ed. Harvard Business Review. Retrieved from 
https://hbr.org/2020/03/what-the-shift-to-virtual-learning-could-mean-for-the-future-ofhigher-ed

Hartman, J., Dziuban, C., \& Moskal, P. (2000). Faculty satisfaction in ALNs: A dependent or independent variable? Journal of Asynchronous Learning Networks, 4(3), 155-177. https://doi.org/10.24059/olj.v4i3.1892

Heckel, C., \& Ringeisen, T. (2019). Pride and anxiety in online learning environments: Achievement emotions as mediators between learners' characteristics and learning outcomes. Journal of Computer Assisted Learning, 35, 667-677. https://doi.org/10.1111/jcal.12367

Hilsenrath, J., \& Kamp, J. (2020, May 9). How a Johns Hopkins professor and her Chinese students tracked coronavirus. The Wall Street Journal. Retrieved from https:/ / www.wsj.com/articles/how-a-johns-hopkins-professor-and-her-chinese-studentstracked-coronavirus-11589016603

Hodges, C., Moore, S., Lockee, B., Trust, T., \& Bond, A. (2020, March 27). The difference between emergency remote teaching and online learning. Retrieved from https://er.educause.edu/articles/2020/3/the-difference-between-emergency-remoteteaching-and-online-learning

Houshmandi, S., Rezaei, E., Hatami, J., \& Molaei, B. (2019). E-learning readiness among faculty members of medical sciences universities and provide strategies to improve it. Research and Development in Medical Education, 8(2), 105-112. http://dx.doi.org.cyrano.ucmo.edu:2048/10.15171/rdme.2019.020

Jaques, D., \& Salmon, G. (2007). Learning in groups: A bandbook for face-to-face and online environments. Abingdon, UK: Routledge.

Joo, Y., Kim, N., \& Kim, N. (2016). Factors predicting online university students' use of a mobile learning management system (m-LMS). Educational Technology Research \& Development, 64(4), 611-630. https://doi.org/10.1007/s11423-016-9436-7

Kirkwood, A., \& Price, L. (2014). Technology-enhanced learning and teaching in higher education: What is 'enhanced' and how do we know? A critical literature review. Learning, Media and Technology, 39(1), 6-36. https://doi.org/10.1080/17439884.2013.770404

Lokken, F., \& Mullins, C. (2014). Trends in elearning: Tracking the impact of elearning at community colleges. Retrieved from http://www.itcnetwork.org/membership/itc-distance-education-surveyresults.html

Martin, F., Budhrani, K., \& Wang, C. (2019). Examining faculty perception of their readiness to teach online. Online Learning, 23(3), 97-119. http://dx.doi.org/10.24059/olj.v23i3.1555

Masciari, E. (2011). Trajectory outlier detection using an analytical approach. In Proceedings of the 23rd IEEE International Conference on Tools With Artificial Intelligence (pp 377-384). Washington, DC: IEEE Computer Society.

Orlando, J., \& Attard, C. (2015). Digital natives come of age: The reality of today's early career teachers using mobile devices to teach mathematics. Mathematics Education Research Journal, 28, 107-121. https://doi.org/10.1007/s13394-015-0159-6

Otter, R. R., Seipel, S., Graeff, T., Alexander, B., Boraiko, C., Gray, J., ... Sadler, K. (2013). Comparing student and faculty perceptions of online and traditional courses. The Internet and Higher Education, 19, 27-35. https://doi.org/10.1016/j.iheduc.2013.08.001

Tabata, L., \& Johnsrud, L. (2008). The impact of faculty attitudes toward technology, distance education, and innovation. Research in Higher Education, 49(7), 625-646.

Tallent-Runnels, M. K., Thomas, J. A., Lan, W. Y., Cooper, S., Ahern, T. C., Shaw, S. M., \& Liu, X. (2006). Teaching courses online: A review of the research. Review of Educational Research, 76(1), 93-135. https://doi.org/10.3102/00346543076001093 
Reisetter, M., LaPointe, L., \& Korcuska, J. (2007). The impact of altered realities: Implications of online delivery for learners' interactions, expectations, and learning skills. International Journal On E-Learning, 6(1), 55-79.

Rockwell, S. K., Schauer, J., Fritz, S. M., \& Marx, D. B. (1999). Incentives and obstacles influencing higher education faculty and administrators to teach via distance. Online Journal of Distance Learning Administration, 2(4). Retrieved from https://www.westga.edu/ distance/rockwell24.html

Singh, R. N., \& Hurley, D. (2017). The effectiveness of teaching and learning process in online education as perceived by university faculty and instructional technology professionals. The Journal of Teaching and Learning, 6, 65-75. https://doi.org/10.14434/jotlt.v6.n1.19528

Siron, Y., Wibowo, A., \& Narmaditya, B. S. (2020). Factors affecting the adoption of e-learning in Indonesia: Lesson from Covid-19. Journal of Technology and Science Education, 10(2), 282-295. https://doi.org/10.3926/jotse.1025

Stickney, L., Bento, R. F., \& Apparwat, A. (2019). Online higher education: Faculty satisfaction and its antecedents. Journal of Management Education, 43(5), 509-542. https://doi.org/10.1177/1052562919845022

Thomas, J. W., \& Foster, H. A. (2020). Higher education institutions respond to epidemics. History of Education Quarterly, 60(2), 185-201. https://doi.org/10.1017/heq.2020.11

Thormann, J., \& Zimmerman, I. K. (2012). The complete step-by-step guide to designing and teaching online courses. New York, NY: Teachers College Press.

United Nations Sustainable Development Group. (2020, August). Policy brief: Education during COVID-19 and beyond. Retrieved from https://unsdg.un.org/resources/policy-briefeducation-during-covid-19-and-beyond

U.S. Department of Education. Institute of Education Sciences, National Center for Education Statistics. (2019). Digest of education statistics. Retrieved from https://nces.ed.gov/programs/digest/d19/tables/dt19 311.15.asp

Vang, K., Martin, F., \& Wang, C. (2020). Examining community college faculty perceptions of their preparedness to teach online. Journal of Applied Research in the Community College, 27(1), 45-63.

Wilson, D., \& Allen, D. (2011). Success rates of online versus traditional college students. Research in Higher Education Journal, 14. https://eric.ed.gov/?id=EJ1068796

Wingo, N. P., Ivankova, N. V., \& Moss, J. A. (2017). Faculty perceptions about teaching online: Exploring the literature using the technology acceptance model as an organizing framework. Online Learning, 21(1), 15-35. http://dx.doi.org/10.24059/olj.v21i1.761 